UDC 811.112.2

DOI https://doi.org/10.32782/tps2663-4880/2021.15.13

\title{
LEXICO-SEMANTIC MEANS OF SENSATIONALISM IN HEADINGS OF GERMAN-LANGUAGE MEDIA TEXTS
}

\section{ЛЕКСИКО-СЕМАНТИЧНІ ЗАСОБИ СЕНСАЦІЇ В ЗАГОЛОВКАХ НІМЕЦЬКОМОВНИХ МЕДІАТЕКСТІВ}

\author{
Liepukhova N.I. \\ orcid.org/0000-0001-7476-559X \\ Candidate of Philological Sciences, \\ Associate Professor at the Department of German Language \\ Nizhyn Gogol State University \\ Shcherbak O.M., \\ orcid.org/0000-0001-9495-4355 \\ Candidate of Philological Sciences, \\ Associate Professor at the Department of German Language \\ Nizhyn Gogol State University
}

\begin{abstract}
Media text is a verbal information carrier which is characterized by intertextuality, pragmatic orientation and social regulation and spread through the press, radio, television, and the Internet. The headline, which is the title of a work, functions to establish contact with the reader, attract their attention and generate interest in the published material. The headline summarizes and foregrounds the most important information in the message and serves as a means of influence on the reader's perception. This approach is considered to be unified in the global information space and can be regarded as a characteristic feature of the prevailing style of the newspaper headline, with a number of its inherent structural, lexicogrammatical, functional and stylistic features. The article is devoted to the study of the German language media headlines in order to identify and classify lexical and semantic means that represent sensationalism. The research is increasingly becoming important due to the fact that the gained results will help to reveal in more detail what linguistic techniques the authors of such headlines use to create the desired effect and will allow a deeper study of the level of sensational texts' emotional impact on the readership. The strategies for generating a sensational headline are directly dependent on the semantic and stylistic potential of the lexical units included in its composition. The main features of media headlines include the author's desire to achieve the greatest expressiveness with the minimum of linguistic units. Sensational headlines are used in most cases for this purpose. Informational content, documentary presentation in headlines fades into the background. Real facts and assessments are transformed into figurative associations or comparisons. Headlines are characterized by manifestation of an individual author's style and expressive lexical and semantic means, which are often introduced, for example, colloquial vocabulary, neologisms, borrowings, unexpected word combinations. Rhetorical techniques are also applied in headlines, for example, metaphor, allusion, puns, antithesis, since their main task is to influence the addressee, attract their attention, surprise and intrigue.
\end{abstract}

Key words: media headline, expressive vocabulary, neutral vocabulary, stylistic figures, German-language.

Медіатекст - це вербальний носій інформації, який характеризується інтертекстуальністю, прагматичною спрямованістю та соціальною регуляцією, поширюючись через пресу, радіо, телебачення, Інтернет. Заголовок - це назва твору, основна мета якого полягає у встановленні контакту з читачем, приверненні уваги та інтересу до матеріалу, що публікується. Заголовок актуалізує найбільш важливу інформацію в повідомленні та виступає засобом впливу на сприймання ії читачем. Такий підхід $€$ уніфікованим у світовому інформаційному просторі і простежується як характерна риса сформованого стилю газетного заголовку, з низкою притаманних йому структурних, лексико-граматичних та функціонально-стилістичних рис. Статтю присвячено вивченню медійних заголовків із метою виявлення та класифрікації лексико-семантичних засобів, що відтворюють сенсаційність. Необхідність такого дослідження зумовлена тим, що пропоновані результати допоможуть більш детально виявити, які лінгвістичні прийоми використовують автори подібних заголовків для створення бажаного ефекту, і дадуть змогу глибше дослідити рівень емоційного впливу сенсаційних текстів на читацьку аудиторію. Стратегії породження сенсаційного заголовку знаходяться в безпосередній залежності від семантичного та стилістичного потенціалу лексичних одиниць, що включаються до його складу. До основних особливостей медійних заголовків варто зарахувати прагнення автора досягти найбільшої виразності за умови мінімальної витрати мовних засобів. Із цією метою використовуються здебільшого сенсаційні заголовки. У них інформаційність, документальність викладу відходить на другий план, реальні факти і оцінки трансформуються в образні асоціації, порівняння, спостерігається прояв індивідуального авторського стилю, часто вводяться експресивні лексико-семантичні засоби, наприклад, розмовна лексика, неологізми, запозичені слова, несподіване поєднання різних слів, використовуються риторичні прийоми, як наприклад, метафора, алюзія, гра слів, антитеза, адже їхнє головне завдання - вплинути на реципієнта, привернути його увагу, здивувати і заінтригувати.

Ключові слова: медійний заголовок, експресивна лексика, нейтральна лексика, стилістичні фрігури, німецька мова. 
Problem statement. The modern improvement of information and communication technologies has contributed to a significant increase in the overall corpus of media texts. People's ideas about what is happening in different parts of the planet are largely due to those images and interpretations, on the basis of which we can talk about the formation of an information picture of the world reflecting the national and cultural characteristics of the world perception and the system of value relations.

The analysis of scientific literature indicates the constant interest of linguists in the issue of headings and the need for further in-depth research of the features of media headings, but the analysis of the reproduction of sensationalism in Germanlanguage media headings has not been carried out yet.

Literature review. The problems associated with the study of the specifics of media headings have repeatedly attracted the attention of linguists. In the early 21 st century, researchers are showing a deep interest in the study of headings in the media. Many scientists (Yu.V. Vereshchynska, M.Yu. Dotsenko, S. Hackl-Rößler) pay special attention to the problems of typification and classification of news headings, their structure, syntactic and functional features, semantics, stylistic specifics $[1 ; 2 ; 3]$. A number of works are devoted to the issue of studying the role of the heading as a representative of the text. In the center of attention of many researchers (H.V. Mykytiv, H.V. Shapovalova) is the consideration of the issue of correlation between the title and the main text $[4 ; 5]$.

The concept of "sensationalism in the media" has been studied in detail in the United States of America, where this phenomenon is closely related to the emergence and formation of the concept of "modern American media" [6, p. 193].

Many American scientists have studied the development of the concept of "sensationalism", as well as its influence on readers. The most significant and fundamental studies, the results of which can be used in the study of the category of "sensationalism", belong to V. Campbell, R. Stevenson, D. Davis, S. McLeod, M. Kalba and others.

Purpose statement. The relevance of our study lies in the fact that it is located at the intersection of two areas of linguistics: the semantic paradigm of linguistic research and media linguistics, and is due to the increased interest of researchers in the issue of identifying linguistic mechanisms of influence on the recipient, in particular sensational media headings.

The purpose of the article is to study the lexical and semantic means that reproduce sensationalism in German-language media headings. For the purpose of the study, the following tasks are solved: to summarize the theoretical material on the definition of the concepts of "headline", "media text" and "sensationalism" in modern media linguistics; to establish the semantic characteristics of sensational media headlines; to determine the information-semantic and functional-stylistic features of the Germanlanguage news headlines.

\section{Research results}

The term "media text" is used closely related to traditional and innovative designations: journalistic text, radio, teletext, newspaper text, network text, hypertext and the like. Translated from Latin "media", "medium" means a means, a method that allows you to call any medium of information as a media text, for example, traditional and electronic books. The media text is understood as a verbal work created for the implementation of mediated communication in the field of mass media, regulated by a clearly expressed pragmatic orientation and social regulation [7]. When creating a media text, three stages are distinguished: orientation, creation of a concept and formulation $[8, \mathrm{p} .12]$. The initial stage is associated with a certain communicative need to communicate something urgent and sensational. At the stage of creating a concept is the optimal implementation of the communicative intention.

The continuity of media text messages is especially evident in the headings. Despite their brevity and repetition, the audience understands them without reading the entire text of the message, which is possible thanks to the keywords that were previously repeatedly mentioned in previous issues of media texts: television, radio, Internet. Thus, the media title, despite the tight framework, can carry out a contact, informative, appellative, indicative and guiding function $[9$, p. $213 ; 10$, p. 256].

At present, there is a wide variety of definitions of the concept of "heading". A wide range of definitions can be attributed to the dual nature of the title. On the one hand, it is a linguistic structure that represents a text (placed above or in front of it) and therefore can be perceived as a linguistic element that is outside the text and has a certain independence. On the other hand, the heading acts as a full-fledged component of the text and forms a single system with it.

The definition of Russian researchers looks interesting, in our opinion, because they argue that the title acts as a dominant function of the text, the purpose of which is to give a clear idea of the content of the message and to draw attention to it [11]. The newspaper heading contains all the reality and all the most important points 
of the message in a light and concise form; according to Yu.V. Vereshchynska's definition, a newspaper heading is a kind of media texts, consists of one or several sentences, that names the newspaper material and those preceding the main text of the article, and also reproduces its major topic [1, p. 18].

A good media heading should influence the reader, and therefore it is always based on correspondence with the content, clarity, accuracy, brightness, expressiveness. The best media titles include those that have the following properties: information content, objective reproduction of text content, originality, expressiveness, expressiveness of thoughts, intonation expressiveness. Based on the above, a good media heading is a concentrated image of the main idea of the work, the main idea of the author, but the image should be as short, laconic, clear, specific as possible.

Thus, a heading is a metatext sign that expresses actual and conceptual information. As a pre-text, it appeals to the reading experience. One of the functions of the heading is an indication of the information presented in the text, because the informativeness of the heading is important for the perception of the general informativeness of the message.

Among the wide range of functions of media headings, the main one is informative, this allows the recipients to form an idea of the content of the message. The intrigue in the heading draws attention to the informational message, while the author does not have to mislead the recipients, because this is a manifestation of disrespect that has its consequences. A media title created on links that are irrelevant to the presented material can become provocative and cause certain hopes in the recipient, a desire to familiarize himself with the content, and as a result, these expectations remain unjustified.

In domestic and foreign journalism, there is almost no fundamental research on the definition and classification of sensation. It is considered as a "hot" news message, which is relevant only for a limited amount of time (then it is distributed by other media outlets, it becomes generally known), its value is estimated according to the following main criteria: the scale of the scandal and its primacy [6, p. 55]. "Sensation striking the imagination, 'turns off' the rationality and opens the way for the effects of thinking, sensuality and behavior uncontrolled by consciousness" [12, p. 193].

With the help of a sensation, one can divide information in such a way that the recipient never has a complete picture of what is happening. Important events are hushed up under the guise of sensations, which the recipients do not know about. The simpler and more sensational the message is, the easier it is to be captured in the mind of the recipients. So, sensation is a manipulative technology. With its help, one can hide many important details or submit false information.

The word "sensation" means a strong, stunning impression of an event, message, or the event itself, the message that creates such an impression. There is a close connection between sensation and emotionality. S. Roshchin's work Psychology and Journalism notes that "any important message that affects the interests of society and its individual representatives must have a certain emotional coloring, that is, an element of healthy, normal sensationalism" $[13$, p. 94]. Thus, sensation can be seen as an effective means of modeling media text.

A universal feature of the German-language media discourse is an expressive accent, that is, the search for new, fresh expressive means - words, images, stylistic devices in order to create a sensation. Expressive vocabulary is traditionally distinguished against the background of proper nominative (neutral) vocabulary. Speaking about the modern headings of German-language media texts, we note that there is a general tendency to borrow expression from oral speech and expressiveness from fiction.

Analyzing the German media discourse, one cannot fail to notice an obvious decline in the speech standard, accompanied by an active intrusion of elements of colloquial speech, which is determined by expressiveness.

Sensationalism in German media headings is achieved primarily by expressive lexical and semantic means ( $82 \%$ of headings analyzed) and, to a lesser extent, by neutral ones (18\% of headings analyzed). The lexical and semantic analysis of headings demonstrates that sensationalism is achieved with the help of expressive vocabulary, realized by colloquial words, exclamations, tropes, vulgarisms, etc.

Media headings containing colloquial words, presented by citing the direct speech of participants in the events, and therefore almost always given in quotation marks. The use of such words in headings is often perceived as a reflection of the speech of participants in certain events, as evidence of the proximity of the author of the message to the described events. Contaminants are a folded phrase, cells of concentration of content, in particular, expressive $[14$, p. 164]. In the headings of media texts, contaminants serve as a means of creating sensationalism, attracting and retaining the attention of recipients. Analysis of the German-language headings showed that they mainly use anthroponymic contaminants. For example, the politician Ms. Ypsilanti deceived her voters by promising not to enter into a coalition with the Left Party (Links), therefore she was 
identified in the press as such anthroponymic contaminants: Jub-el (joy, delight) + Ypsilanti $=J u b-$ ilanti/Jammer (grief) + Ypsilanti $=$ Jammer-lanty in the heading VON JUBILANTI ZU JAMMERLANTI (20.11.2008, bild.de).

During the analysis of media headings, one toponymic contaminant was identified in the heading Abrechnung mit der Ostalgie (21.11.2011, bild. de). The toponymic contaminant Ostalgie parodies the concept of Nostalgie, because its first component Ost (east) symbolizes the disappeared GDR, associations with which in most of the population of the former Germany cause a negative reaction.

Tropes derived from the headings under consideration include antithesis, metaphor, allusion, and the like.

Antithesis is "a stylistic figure built on the emphasized opposition of opposite phenomena, concepts, thoughts, feelings, images to enhance expressiveness" [15, p. 46]. In the course of the analysis, it was revealed that the communicative-pragmatic attitudes of media titles are manifested through the methods of opposition, are implemented by lexical and contextual antonyms. They help to increase the credibility of the addressee's words, since the addressee has the opportunity to compare. The antithesis is based on an antonymous pair. The concept of antithesis expresses a sharp opposition, which gives the author the opportunity to create an extremely expressive, three-dimensional image.

Antonyms in headings are mainly characterized by full grammatical relativity. These words belonging to the same part of speech have the same grammatical indicators (gender, number, case, time, face, image), for example, in the title: Neues Lager, alte Probleme (09/21/2020, https://www. sueddeutsche.de/politik/ camp-moria-neues-lager-fluechtlinge-1.5039542). In the above example, the antithesis is accepted, expressed by the adjectives neu and alt with antonymic meanings. To the lexical-semantic means realizing the antithesis, we also include the double conjunction $m a l . . . m a l$, which contrasts certain parts of speech, as in the heading Mal 500 Gäste, mal nur 50 (09.24.2020, zeit.de) about a sharp change in the number of patients for coronavirus.

Metaphor is an artistic means, which consists in the figurative use of a word or expression based on analogy, similarity or comparison, as well as the word or expression taken in this way [16; 17].

During the analysis of German-language media headings, it was found that the metaphor is used mainly in the headings of sports messages. Der totale Kahnsinn! in the report of the German magazine Focus, in an article on the internal problems of the Bayern club, for which Oliver Kahn spoke, contains the metaphor Wahnsinn (Wahnsinn - madness, recklessness) (focus.de, 22.04.2019.).

The analysis of media headings revealed the following metaphors "Minister im Sturm" (08.04.2016, sueddeutsche.de), "Das grüne Gold und sein blutiges Erbe" (09.04.2019, sueddeutsche.de), "Die Waffen der Frau" (14.03.2019, zeit.de), "Im Zug der Zeit" (14.03.2019, zeit.de), "Auf der Kippe" (28.03.2019, zeit.de), "Die Karawane stoppen" (09.04.2019, sueddeutsche.de).

Allusion in philology is an adapted translation of the word "hint" in Latin, but in most European languages the word "allusion" means only denotation, which in Ukrainian is expressed by the word "hint" [18, p. 23]. In the media headings analyzed in this study, the use of allusion is aimed at achieving a humorous, ironic, comic effect, indicating the closeness of journalism broadcasting and colloquial speech.

An article titled "Eine amerikanische Tragödie" (sueddeutsche.de, 09/11/2016) discussed the results of the US presidential election, which was won by Donald Trump. In the given title, an allusion with a negative and ironic connotation is used, which manifests an analogy with the literary novel by $\mathrm{T}$. Dreiser under the same name American Tragedy.

Since "exclamations are able to express joy, delight, fear, disgust, pity", the authors of the message resort to their use in order to provide sensationalism to the message, emphasizing the attitude of the author of the message to the described events [19, p. 45]. Headings containing exclamations, like headings in which colloquial vocabulary is accepted, are also submitted in quotation marks, for example: "Ach, Herr Verkehrsminister" (01.08.2019, sueddeutsche.de), "Wipp, wipp, hurra" (31.07. 2019, sueddeutsche.de), "Hurra, wir haben beim Glücksdreh gewonnen!" (07.10.2020, bild.de).

Neutral vocabulary - these are words that do not have a stylistic connotation and stylistic purpose, can be used with equal success in all styles. Sensationalism in media titles is reproduced by lexical units with the semantics of improbability, with the semantics of shock, with the semantics of sensation.

The vocabulary with the semantics of improbability is represented by the adverbs unglaublich, unfassbar, frappierend. For example, the head of Unfassbar: OB-Kandidat in Mönchengladbach für tot erklärt attracts the attention and interest of recipients, and the content of the adverb unfassbar is revealed after the colon, which specifies what is incredible, unexpected: the death of a candidate for the post of mayor of the city of Mönchengladbach. 
The vocabulary with the semantics of shock is designed for a psychological reaction "to a completely unexpected experience, stress, for which the individual was not prepared" [20, p. 244]. In the following example, a common noun with shock semantics Schock is combined with the adjective historisch: "Historischer Schock" für die Wirtschaft (tagesschau.de, 04/27/2020) about the economic crisis in the United States led by the Coronavirus.

Sensational headings are represented by a common noun for sensation itself - Sensation, which is combined with common nouns semantics that deals with sensation. For example, the sensationalism in the heading manifests itself through the common noun Sensation, which interacts with the common noun Produkt, which explains what the sensation is about: Neues Getränk: Coca-Cola plant nach 126 Jahren echte Produkt-Sensation (express.de, 09.09.2020).

Abusive vocabulary refers to profanity and has nothing to do with the addressee, since it speaks more about the addressee, his imbalance or bad manners, a tendency to vulgarity, inability to restrain his emotions. To abusive words belong the vulgarisms "Arsch", "Scheiße", semi-prefixes Scheiß-, scheiß-, which are attached to nouns and adjectives, give them an expressive-evaluative derogatory meaning [21, p. 334]. Abusive words in headings are always given in direct speech and may not be printed to the end, which is why the author Satti hesitates to use this word, as in the heading "Alles Schei...": Ungewöhnliche Schau im Naturkundemuseum (12.11.2020, sueddeutsche.de)... The author of the post used the swear word "Arsch" in the heading "Corona hat uns den Arsch gerettet" (bild.de, 01.10.2020).

Neologisms are used in headings in order to introduce new expressive figurative elements into certain established stereotypes. During our research, both general linguistic and individual-author's neologisms were identified.

General linguistic neologisms are words that are understandable to all participants in the communicative process, but have not yet become a lexical norm. The general linguistic neologism Corona-Leugner for denoting persons who do not recognize a coronavirus infection is adopted in the heading Streeck antwortet auf Theorien der "Querdenker" und Corona-Leugner (21.09.2020, express.de). A separated general linguistic neologism is combined in the heading with the colloquial lexical unit Querdenker to denote persons who think outside the box. The interaction of these units denotes something new, non-standard, giving the heading sensationalism. The neologism Wohlstandsmüll (waste of wealth), denotes a con- temptuous attitude towards people who do not want or are unable to work. A common linguistic neologism adopted in the title Wühlen im Wohlstandsmüll (13.05.2019, neuepresse.de).

Individual author's neologisms can be represented both by separate words and by the message of separate words from anthroponyms, and which did not exist in the language, but were invented by the authors of the messages, such as in the title "Antisemiwas?" (23.04.2018, faz.net). The author of the post understands that recipients will be interested in reading the news under this heading, as they will want to know what the word Antisemiwas means. Another individual author's neologism Vier-Gefühl - is found in the title of an article about the victory of the German national team at the World Cup Das Neue Vier-Gefühl! Selbstbewusst, gemeinsam, kämpferisch, modern (14.07.2014, bild.de). The heading consists of two sentences, the first contains the author's neologism, and the second is a stylistically colored amplification of four epithets that reveal the meaning of the neologism. We refer to the individual-author's neologism the unit überdramatisieren in the heading Lindner zu Corona-Maßnahmen "Nicht überdramatisieren" (18.10.2020, tagesschau.de).

A paradox is a kind of thought, reasoning, sharply at odds with the usual, generally accepted and contrary to common sense; unexpected, incredible phenomenon, does not correspond to the usual ideas [20, p. 199]. The paradoxical combination of names with common nouns arouses the interest of recipients and creates a sensational effect due to the fact that the names are already known, as a rule, to recipients, therefore, their unusual combination with other units is of interest.

The paradoxical connection of anthroponyms with common nouns is designated as individual author's anthroponymic neologisms, such as BibiSitter and Brexit-Boris, in which the components are anthroponyms, which are played up with the interaction of Sitter and Brexit parts in the headings Der Bibi-Sitter (03/28/2019, zeit. de) and Brexit-Boris muss den Gürtel enger schnallen (21.09.2020, bild. de), respectively. In both titles, individual author's neologisms implement a play on words. In the first heading Der Bibi-Sitter "Bibi" is the nickname of Benjamin Netanyahu, from the English "baby-sitter" (nanny) and in the second heading - Brexit-Boris muss den Gürtel enger schnallen where "Boris" denotes Boris Johnson.

Conclusions. Thus, sensational headings appeal to the emotions of the recipients and induce them to open a link, which contains common news, the content of which does not reflect the heading. The lexi- 
cal expressive fund includes, first of all, units associated with a departure from standards and stereotypes that are focused on unexpected associations: colloquial vocabulary, antithesis, metaphor, allusion, neologisms, and an unusual combination of names with common nouns. The brightness and diversity of the stylistic means adopted in the media headings are always motivated by a certain idea. The author of the message uses the language that is used in an informal setting, in conversation on relevant topics with people close and familiar. Thanks to this, the author of the message not only expresses his attitude to the events that are presented, but also tries to attract the attention of recipients by providing sensationalism to the events indicated in the headings. Further research problems include the study of the specifics of the translation of sensational media headlines.

\section{REFERENCES:}

1. Верещинская Ю.В. Заголовки газетных статей в аспекте медиалингвистики (на материале испанского языка). Филологические науки в МГИМО : Сборник научных трудов. 2007. № 28 (43). С. 17-25.

2. Доценко Е.Л. Психология манипуляции: феномены, механизмы и защита. Москва, 1997. 308 с.

3. Hackl-Rössler S. Textstruktur und Textdesign. Textlinguistische Untersuchungen zur sprachlichen und optischen Gestaltung weicher Zeitungsnachrichten. Tübingen: Narr, 2006. 225 S.

4. Микитів Г.В. Інтерпретація газетних заголовків у сучасному інформаційному просторі. Вісник Запорізького національного університету : збірник наук. пр. Філологічні науки. 2010. № 1. С. 233-237.

5. Шаповалова Г.В. Лексико-стилістичні особливості заголовків у сучасних українських друкованих $3 \mathrm{MI}$. Ученые записки Таврического национального университета им. В.И. Вернадского. 2011. № 4. Часть 1. Том 24 (63). C. 204-210.

6. Вайшенберг 3. Журналістика та медіа: довідник / 3. Вайшенберг, Г.Й. Кляйнштойбер, Б. Пьорксен. Київ : Центр Вільної Преси, Академія Української Преси, 2011. 529 с.

7. Рогозина И.В. Медиа-картина мира: когнитивно-семиотический аспект : автореф. дис. ...докт. пед. наук : 10.02.19. Барнаул, 2003. 43 с.

8. Sommerfeldt K.-E. Gestern so und heute anders. Sprachliche Felder und Textsorten in der Presse. München: ludicium-Verlag, 1997. $171 \mathrm{~S}$.

9. Brand W. Zeitungssprache heute: Überschriften. Aspekte der Textlinguistik. Olms, 1991. S. 213-244.

10. Fehr-Buchter C. Linguistisches Profil zweier Schweizer Tageszeitungen. Bern u.a.: Lang, 1994. 288 S.

11.Александрова О.В. Проблемы экспрессивного синтаксиса: На материале английского языка : учебное пособие. Изд 2-е, испр. Москва : Книжный дом «ЛИБРОКОМ», 2009. 216 с.

12. Westerbarkey J. Die Assimilationsfalle, oder was eigentlich vorgeht. Ein Plädoyer für anschlussfähige Unterscheidungen. Leitbilder von gestern? Zur Trennung von Werbung und Programm. Wiesbaden: Baerns, Barbara (Hrsg.), 2004. S. 193-204.

13. Рощин С. Психология и журналистика. Москва: Наука,1989. 183 с.

14. Моісєєва Н. Семантичні та функціональні особливості німецьких контамінованих лексем. Наукові записки національного університету «Острозька академія». Серія «Філологія», 2015. Вип. 55. С. 163-165.

15. Павличко Д.В. Твори: в 3 т. Т. 2. Поезії. Київ : Дніпро, 1989. 542с.

16. Матвеева Т.В. Полный словарь лингвистических терминов. Ростов-на-Дону : Феникс, 2010. 563 с.

17. Українська мова. Енциклопедія / редкол. В.М. Русанівський, О.О. Тараненко, М.П. Зяблюк та ін. Київ : «Українська енциклопедія» ім. М.П. Бажана, 2000. 820 с.

18. Сучасний тлумачний словник української мови : 65000 слів / за заг. ред. д-ра філол. наук, проф. В. Дубічинського. Харків : Школа, 2006. 1008 с.

19. Кропіна С.А., Лазебна О.А. Оцінність як текстотвірний складник публіцистики (на матеріалі сучасної німецької мови). Науковий вісник Міжнародного гуманітарного університету. Серія: Філологія. Одеса : «Гельветика», 2019. Вип. 39. Т. 2. С. 43-46.

20. Психологічний словник / авт.-уклад. В.В. Синявський, О.П. Сергєєнкова / за ред. Н.А. Побірченко. Київ, 2007. $336 \mathrm{c}$.

21. Perrin D. Medienlinguistik. 2. überarb. Aufl. Konstanz: UVK-Verl.-Ges., 2011. 258 S. 